\title{
What's post racial discourse got to do with it? Obama and the implications for multiculturalism in college classrooms
}

\begin{abstract}
Jennifer Thorington Springer ${ }^{1,2}$
Abstract: With the election and re-election of Barack Obama as the first Black President of the United States came the vexing yet perhaps expected conclusion that issues of race and ethnicity were no longer grave concerns. Somehow Obama's presence suggests the transcendence of race. While a nod to the political progress made in terms of social race relations may be in order, Obama's election does not translate into a "color-blind," "post race" American nation. This essay explores how current and ongoing conversations about a post race nation shape student perceptions of race and how they directly affect the teaching instruction of professors, like myself, who are invested in multicultural and inclusive pedagogy. As an instructor invested in inclusive learning, my former struggle of getting students to understand the importance of acknowledging the validity of cultural differences has resurfaced as students who buy into the rhetoric of a "post race" nation no longer think it necessary to examine closely racially charged inequities. Rather than adhere to the problematic ideology of Obama as the embodiment of a "post race" nation, I propose an exploration of his identity and politics as those that encourage fluidity and cultural plurality without denying rightful acknowledgement of race as a viable political reality.
\end{abstract}

Keywords: Multicultural teaching, inclusion, race, post race, Barack Obama, black.

\section{Introduction}

The value of a multicultural and inclusive education is well established and has been embraced steadily by educators who recognize the ways in which the employment of cultural diversitythrough the use of varied texts and student centered class discussion-makes for a more enriching educational experience. "Multiculturalism is now a given ... it has arrived" (Asher 2007). As an instructor whose teaching career began in the early 1990s when the fight for inclusive teaching was at its peak, it is rewarding to note progress. However, it seems that the post racial rhetoric that permeates recent scholarship and social media net works due to the election of a black U.S. president has somehow interrupted the progress of a multicultural education. More importantly, the attack on multicultural and inclusive pedagogy is racially based in that students believe we no longer have a need to address issues of race because racism no longer exists. There is no need for an engagement with multicultural anything furthermore a discussion of race within the context of multiculturalism. While the primary focus in this article is on the politics of racial

\footnotetext{
${ }^{1}$ Associate Professor of English, IUPUI, jtspring@iupui.edu

2 While I fully embrace the fact that multicultural teaching does not begin and end with race, this essay is interested in the conversations surrounding race as it pertains to Obama's election and what this outcome means for the future of multiculturalism and inclusive teaching within college classrooms.
} 
identity and post-race attitudes, the assumption that multiculturalism only encapsulates racial identities is not being made (though students seem to embrace this belief). The problematic mainstream understanding that multiculturalism is simply a tool to challenge racism and allow blacks a seat at the table perhaps evolved from earlier conversations where the importance of multiculturalism did begin with discussions of race, notably blackness, due to the absence of productive discussions about black identities within college based classrooms. Multiculturalism is far more complex and inclusive as it aims to validate all cultures. How will the post race consciousness of my students affect their responses to the inclusion of literature, which examines the state of blackness, black identities, and black culture within and beyond the USA? Multicultural teaching is indeed an important tactic through which the value of diversity and inclusivity is imparted and the skill of cultural competency attained (Banks, 1994). How, then, does one manage students' desire to discuss specific sites of cultural representation and ethnicities instead of others? What is it with race and this thing called blackness, in particular, that students want to avoid? This paper explores the effect of post race rhetoric and its negative influences on student perceptions of race (and other marginalized identities), and how it directly affects the teaching instruction of professors, like myself, who are invested in multicultural and inclusive pedagogy. Rather than adhere to the problematic ideology of Obama as the embodiment of a "post race" nation, I propose an exploration of his identity and politics as those that encourage fluidity and cultural plurality. From this perspective, there is still a need to wrestle with the politics of race as a viable site of exploration and inclusion within classroom discourse. As Kwame Ture articulates, "Black visibility is not black power" (quoted in Ball, 2008). Furthermore, "post racial narratives sever contemporary racial reality from historical events that shaped it and suggest that the consequences of systemic racial oppression ended" (Rossing, 2012). This current Obamaesque moment can allow for a useful evaluation of how to formulate more complex discussions about race and its place within multicultural and inclusive educational practices. An overall exploration of post racial attitudes will lead to a conversation about other post identity orientations that circulate popular culture and Obama's recognition of these.

\section{Race, Multiculturalism, and Resistance: A Brief Review of the Literature}

As the diversity of our communities increase so does the student population in higher education. It is ever clear that multiculturalism is no longer a buzzword. It is understood that it is the moral obligation of higher education to accommodate diversity and transform itself according to the various cultures that compose it (Wlodkowski \& Ginsberg 1995). While race is not the only viable way to adhere to or address issues of diversity it is safe to say that most of our scholarly conversations about inclusive teaching and the need for it began using racial inequities as a starting point: "Multicultural education is a product of the U.S. context and exemplifies the highest democratic ideals. It is committed to developing techniques for achieving educational equality, particularly for students from ethnic groups who historically have been marginalized, dispossessed, oppressed, miseducated, and undereducated in schools. The greatest contributions it can make to building egalitarian society is to function as an instrument for translating equity policy into educational practice" (Gay 2004). Studies also report that not only underrepresented students benefit from a multicultural education but all students, even those who are benefactors of the privilege commiserate with membership in the dominant group (Kitano 1997, Hirtado, Milem, Clayton-Pierdson, \& Allen, 1999, Banks 2005). The audience of multicultural 
educational experiences has expanded and so have our definitions to be more inclusive, and rightly so. However, it seems that the more inclusive our conversations become and the broader in range our definitions of multiculturalism, the less fashionable it is to raise issues of race. Who or what is responsible for the relapse in our fear of "race?"

W. E. B. DuBois was legendary in deeming the $20^{\text {th }}$ Century as one that would be plagued with questions of the color line, especially in the U.S. Here we are in the $21^{\text {st }}$ century and perhaps at our most multicultural existence as a nation, yet the color line and its positioning within discussions of multiculturalism is still being called into question. The legitimacy of race continues to be at the helm of and directly affects our engagement with conversations about race within and beyond the classroom. The distinctive struggle for recognition, rights, and resources by those from underrepresented groups makes the critical examination of race an important aspect of identity conflicts. Perhaps this has much to do with the fact that race has and continues to be the most powerful and persistent group boundary in American history, "distinguishing to varying degrees, the experiences of those classified as non-White from those classified as White, with often devastating consequences (Cornnell \& Haartmann 1998). If all can stand to benefit, where does the resistance come from and what enables such a response? Resistance comes in various forms and is acted out by students and instructors alike.

Students: Resistance to multiculturalism within the curriculum/classroom as it pertains to race could indeed stem from the discomfort that some students experience due to the fact that it causes us to engage with a troubled U.S. history where some groups were discriminated against. Power and privilege of the dominant group is exposed: "This understanding of multiculturalism includes an examination of the experiences of peoples that have been unrecognized in traditional American histories. This can be a fascinating journey for students. However, it also leads to a painful examination of American history as conquest, exposes the legal disenfranchisement of non-European groups, and addresses the structural inequities maintained in current public policies" (Chan \& Treacy 1996). Such responses are indicative of the guilt white students would rather not experience and indeed challenges the status quo (Gay 2004). Furthermore, if students do not necessarily believe that learning about "the other" could enhance their own understanding of self, they will resist and instructors should be prepared for this resistance (Chan and Treacy 1996).

Instructors: Although instructors understand the need to teach their courses from a multicultural standpoint, their resistance stems not from an unwillingness to acquiesce to the call for multicultural curriculum or classrooms. They feel ill equipped and unable to accommodate the needed shift to be inclusive in that there is "a general lack of knowledge of the necessary content and pedagogy required. Most often, instructors state that they do not have the knowledge base to cover topics of diversity within their discipline ... there is simply not enough time to attempt to transform their courses in this manner" (Khaja \& Thorington Springer 2010). There is also the fear of not being able to navigate the emotionally charged conversations that occur during class discussion (Nagda et al., 1999).

The evaluation of student and instructor resistance to multiculturalism has resulted in the production of effective best practices. The implementation and use of texts in syllabi that are written by members of the dominant group that are sensitive to issues of diversity and equity (Thorington Springer 2006). If students, for example, do not trust hearing about racial inequities from instructors who are of a minority background for fear of an overly political agenda, they are perhaps more likely to engage with a text created by some one who shares dominant group status. Pedagogical tools and strategies should be incorporated to ensure a safe space (Sheets 
2005), critically explore differences, and hopefully appreciate such differences in an interactive, dynamic, and flexible learning environment (Banks et al., 2001; Sheets 2005). It is important that instructors create assignments that are conducive to recognizing the value of each individual voice by way of journaling and sharing in class (Hooks 1994). There is also value in instructors who are willing to give up some of their power as instructors to afford students selfempowerment as well as ensure that they do not make any underrepresented student the token representative of that group (Hooks 1994).

Implementation of these listed best practices can and have successfully improved classroom dynamics where there was open resistance to multiculturalism in any form. A look at my own syllabi, peer reviews of my teaching, student assessment, and positive student responses to my inclusive pedagogy testify to the success achieved with the above applied strategies; however, in 2008 after the election of President Barack Obama, the threat of another possible "Battle Royal" looms. ${ }^{1}$ Recent attempts to broach the issue of race within classroom discussion have been met by a new type of resentment. Students are no longer questioning, "why are you trying to force multiculturalism down our throats?" The new mantra has become, "...but a black man is president. Race is no longer an issue. We are so past this. What more do black people want?" While it is true that Obama's election some how "embodied the hopes of many Americans eager to see an often divided nation finally come together to full-fill its egalitarian ideals and step beyond it stains of inequality, segregation, and slavery," (Swarns 3) warrants concern about students who so vehemently buy into this idea that the presidency being occupied by a black man somehow guarantees an egalitarian state. As Kent Ono writes so aptly: "if in America anyone can become President, because Barack Obama became President, and because he is Black, then racism can no longer be used as an excuse for not succeeding. The underlying message here is: Quit complaining, "be like Barack" (reminiscent of old "Be Like Mike" campaigns featuring basketball phenom, Michael Jordan" (Ono 229). The presence of a black president, then, functions as a backlash to progress in the area of multicultural teaching, and fuels post race narratives that make it difficult to challenge or address systemic racism and random racist acts.

\section{Where is the Post in Post Racial Politics? The Myth of Post Raciality}

In a recent course on women writers, my students were eager to talk about the experience of Latino Americans in the US through our critique of Sandra Cisneros' A House on Mango Street; they made room for the exploration of the coming of age narrative of a young Nigerian girl, whose father was tyrannical, as we examined Chimamanda Ngozi Adichie's Purple Hibiscus. Yet, when we came to Edwidge Danticat's Breath Eyes Memory, there were frowned faces and much seat shifting when the issue of race was broached within an American context. Cisneros afforded an opportunity to discuss student's immediate concerns about migratory laws and the increasing numbers of Mexican Americans in "their" neighborhoods. Purple Hibiscus allowed discussions about an affluent African family during a time of civic and political unrest, something they found intriguing yet distant, enough to recuse them of any direct relationship to the challenges faced by Nigerians represented in the novel. Purple Hibiscus as the discussion of blackness was limited to this far off foreign place-Nigeria. Danticat's novel initiated discussions about black migratory experiences, the racism meted to Haitian Americans, and the traumas associated with cultural dislocation. Once I queried the resistance to discussing blackness within an American context, the response aligned with post race idealism: we are a post race nation

Journal of the Scholarship of Teaching and Learning, Vol. 14, No. 3, August 2014. 
because the US has elected a black president. My students appear to interpret post race to mean that the presence of a black president suggests that racial stereotypes had been broken and race transcended. No longer would a black person be disadvantaged or discriminated against due to racial status. These sentiments were held mostly by my white students while the few students of color argued for a different type of raced nation based on their individual and collective experiences, not one that was post but one that continued to demonstrate racial inequities.

The term post race seems to escalate whenever there is a major shift or achievement where a black person occupies a visible position of power, receives notoriety, or celebrity acclaim. Such success reinforces the myth of the American dream, which maintains that a good work ethic affords any individual access to privilege regardless of one's subject positioning. This myth ignites the color blind state of mind. The color blind hopeful's desire for equal opportunity for all in turn fuels the claim to a post race nation. This hope is understandable considering the contentious nature of discussions on race, the emotions that are conjured and the tension that often evolves when whites and non-whites are seated at the table. However, a color blind outlook does not erase racial inequities; it's turning a "blind eye" to an issue that is inescapable. More importantly, color blind rhetoric stunts conversations about difference and perhaps even creates opportunities for what Bernadette Marie Calafell calls the continuance of the "uncritical centering of whiteness" (242). Post race discourse can lead to a re-centering of whiteness and majority ideals.

While it is indeed true that blacks within the US have made progress in attaining some of the benefits of being US citizens, there are still major racial inequities and cultural dislocations that limit the success of blacks and ultimately their freedom to citizenship rights (Alexander, 2012; Hill, 2009; Rossing 2012). In fact, the claim of a post race nation is yet another way to prevent necessary challenges to white supremacy, thus making it difficult to address ways to rectify the disparities and inequities at work within US communities and institutions. Race and racial politics are at the core of American discourse and sustained through education:

... race has been and remains the most intractable problem in the United States. Race defines and shapes the dichotomous social and human relations that have historically specified the juxtaposition of the supremacy, right, privilege, and morality of the 'white' and 'non-white.' In specific terms, race is a marker that describes, informs, and bounds white and nonwhite people within structures of power and domination. If we accept race as a social construction, then we must also accept it as a category by which all groups in the American society are identified. We must also understand that while whites possess race, they are not raced. To be raced in the American society is to be identified as nonwhite. Historically, this especially has been the case for black people.

(Hill, 2009)

Race as a critical site of inquiry cannot be dismissed as easily as post race believers would have it. Whether we perceive Obama ran for office under the guise of a "black man," "multi-ethnic," or "post racial subject," the fact remains that race was at the core of public and private conversations-making it important for us as educators to reexamine and restore race/racism as a part of the multicultural agenda (Ladson-Billings 1996). Obama was accused of not being black enough by some blacks, and not white enough by some whites. The "color blind" posse perceived him as verifying their cause because he was "race-less." However, the very fact

Journal of the Scholarship of Teaching and Learning, Vol. 14, No. 3, August 2014. 
that race was constantly at the center of discussion reinforces its importance and the fact that we cannot be post race. The persistence of racial inequities is a testimony to the fact that we are a race/d nation. Disparities include but are not limited to: the numbers of black men and women incarcerated in comparison to white males and females, respectively (Alexander 2012); unjust treatment of black youth in prosecution of the Jenna 6; the racial profiling of black males, namely Trayvon Martin who was brutally murdered because he "looked suspicious," etc. Perhaps it is highly likely that the very presence of a black president creates a backlash, one where racism peaks rather than decreases; racist propaganda increased during Obama's campaign and after his election. Studies have shown that with the election of a black president racial bias does increase, as there will be less support for policies that are designed to improve racial inequities (Kaiser et. al., 2009). We are taught race through various mediums, the classroom included:

Schools are part of how race is maintained through race's pedagogical dimensions. In other words, educators daily teach young people the naturalized status of race, its foreverness. Educators may question racism, but they rarely interrogate the status of race. The color-blind teacher is perhaps most guilty of this crime as s/he enacts race while denying its reality, but s/he is not the only one who takes race for granted.

(Leonardo, 2011)

What must racism look like for us to acknowledge that we are not post race? What signals or signifiers are needed to shut down this faulty rhetoric? Why are students hearing the post-race rhetoric and ignoring the race centered conversations? If we look closely enough, the very media forms and sites that confirmed a post race nation are writhe with blatant representations of racist responses to primarily Obama's blackness and ethnic identity. Figs. 1 and 2 listed below are two among many overtly racist attacks. Both demonstrate the fact that racial politics are inherent in evaluations of Obama as well as confirm that race/racism is alive and well in our individual conscience.

\begin{tabular}{|l|}
\hline Racially Motivated and Offensive Statements By Tea Partiers \\
\hline "Obama's Plan: White Slavery" \\
"The American Tax Payers are the Jews for Obama's Ovens" \\
"Barack Hussein Obama: The New Face of Hitler" \\
"Barack Obama Supports Abortion, Sodomy, Socialism and the New World \\
Order" \\
"Obama Was Not Bowing. He Was Sucking Saudi Jewels" \\
http://www.huffingtonpost.com/2009/04/16/10-most-offensive-tea- \\
par_n_187554.html\#s20069\&title=Most_Offensive_Tea
\end{tabular}

Figure 1. 


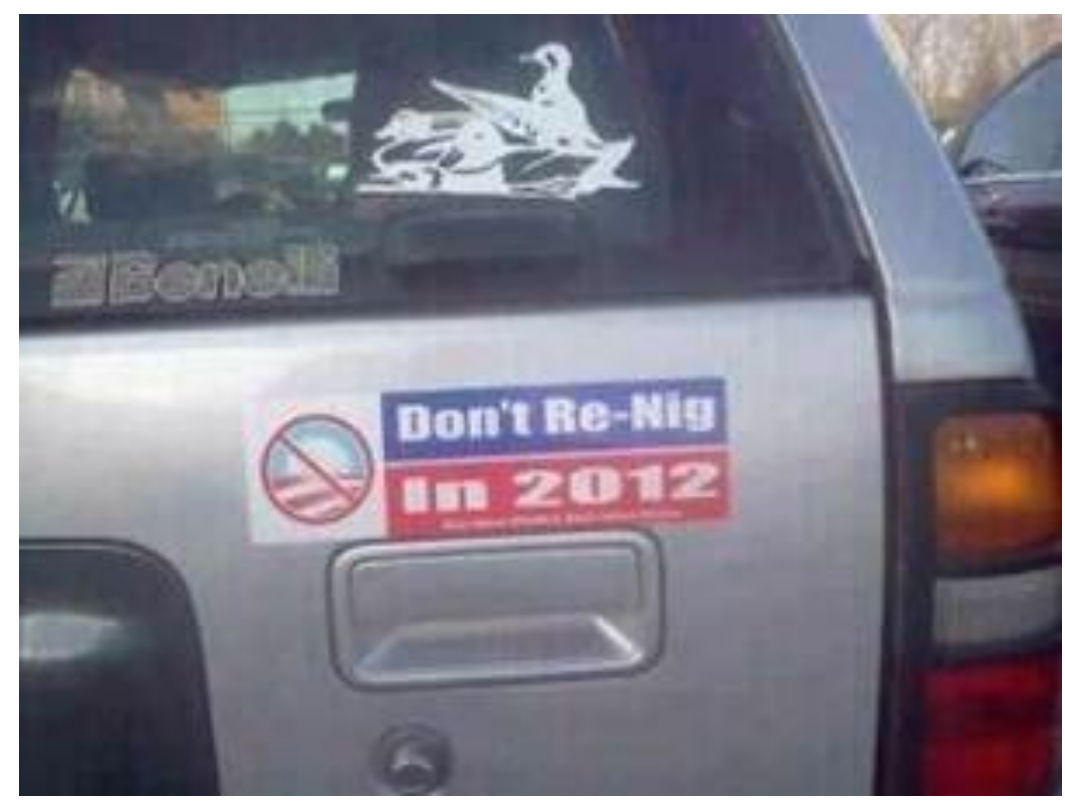

Figure 2.

Figure 1 illustrates the current state of racial politics within the US rather than a post racial era. Statements listed here illuminate a current imbalance of power and the fear majority group members have of losing that power. The proponents of the above listed ideals, thus, embrace the idea that Obama's election would mean a reverse of power where whites are disempowered and blacks empowered. We are a nation shaped by a politics of racial divisions as race is constantly at the forefront of existing politics. Race Matters! ${ }^{2}$ Figure 2 went viral in summer 2012. This bumper sticker goes beyond a simplistic critique of Obama's reign or a political stance that opposes his current campaign for re-election. Its racist overtones are blatant and undeniable. How can this type of rhetoric demonstrate a post race nation? The fact alone that a printing company would publish such racist propaganda is jarring. How can this contradictory language, which counters a post race existence, be accepted? It seems that this claim to a post race nation is being done to erase white guilt and the stigma, which labels whites as racist. Claims for a post race nation is a sophisticated form of racism that allows the benefactors of white privilege an opportunity to escape the discomfort that discussions of race incur. Hence, there is still a need to grapple with the politics of race as a viable site of exploration and inclusion within classroom discourse.

Arguing that Obama embraced a kind of Kingian (Martin Luther King Jr.) strategy, Hill writes that his (Obama's) political resume "demonstrated his capacity to reach across racial and ethnic lines to see that his political viability was inextricably linked to a broad, complex human mosaic" (Hill, 2009). Radhika Parameswaran takes this argument a little further to discuss Obama as one whose successful presidential candidacy expands and reduces the meanings of Blackness in relations to transnationalism. Parameswaran argues that the "Third World" vision of black America that was marketed to the world during Hurricane Katrina was challenged by Obama's biography as it produced new tropes of black identity that "registered both the viability of the 'American Dream' and a cosmopolitan sensibility" (Parameswaran 2009). I would add to Hill and Parameswaran's approaches, here, what others have surmised: Obama's visibly marked subject location as a black man (due to the one drop rule) serves as a compelling symbol for blacks within the US. Even those who claim color blindness have to agree that Obama's presence 
as a black man in such a prominent position is inspiring to young black boys and girls and functions as a collective victory for black communities (see Fig.3 above), namely those who have fought civil rights battles long and hard helping to make his election possible. Fig. 3 published in the New York Times, 2012, tells the story of a young black boy who asked the president, "Is your hair like mine?" When Obama invited the boy to touch his hair, his resolve was "it is like mine." "It is like mine" translates into "we are alike" and "I can potentially become president." Obama's presence adds a new face to American politics on many levels: his ability to build and encourage coalitions among diverse bodies; encouraging a better understanding of who we are as citizens but paying attention to the outside world in order to become global citizens; and, demonstrating that color blindness is not the answer to racial politics. It becomes important to further complicate where we are as a raced nation and figure out the direction to be taken. How then might we apply Obama's celebration of multicultural experiences along with his own multicultural existence for a more successful classroom experience for students and instructors alike? How might we help students to see that conversations of race still belong in multicultural approaches to teaching? How can students of color benefit from inclusive teaching and not be rendered invisible again, due to post race rhetoric that does not want race as critical dialogue? In the remaining paragraphs of this section, I reference statements made by Obama during specific events-important to some of the issues at the center of a multicultural education-such as addresses to the nation, speeches, etc. I then use these statements to convey how the ideology behind them are and can continue to be effective in our pedagogy and our classrooms.

“Is Your Hair Like Mine?” The Need for Race to Remain Part of the Multicultural Classroom

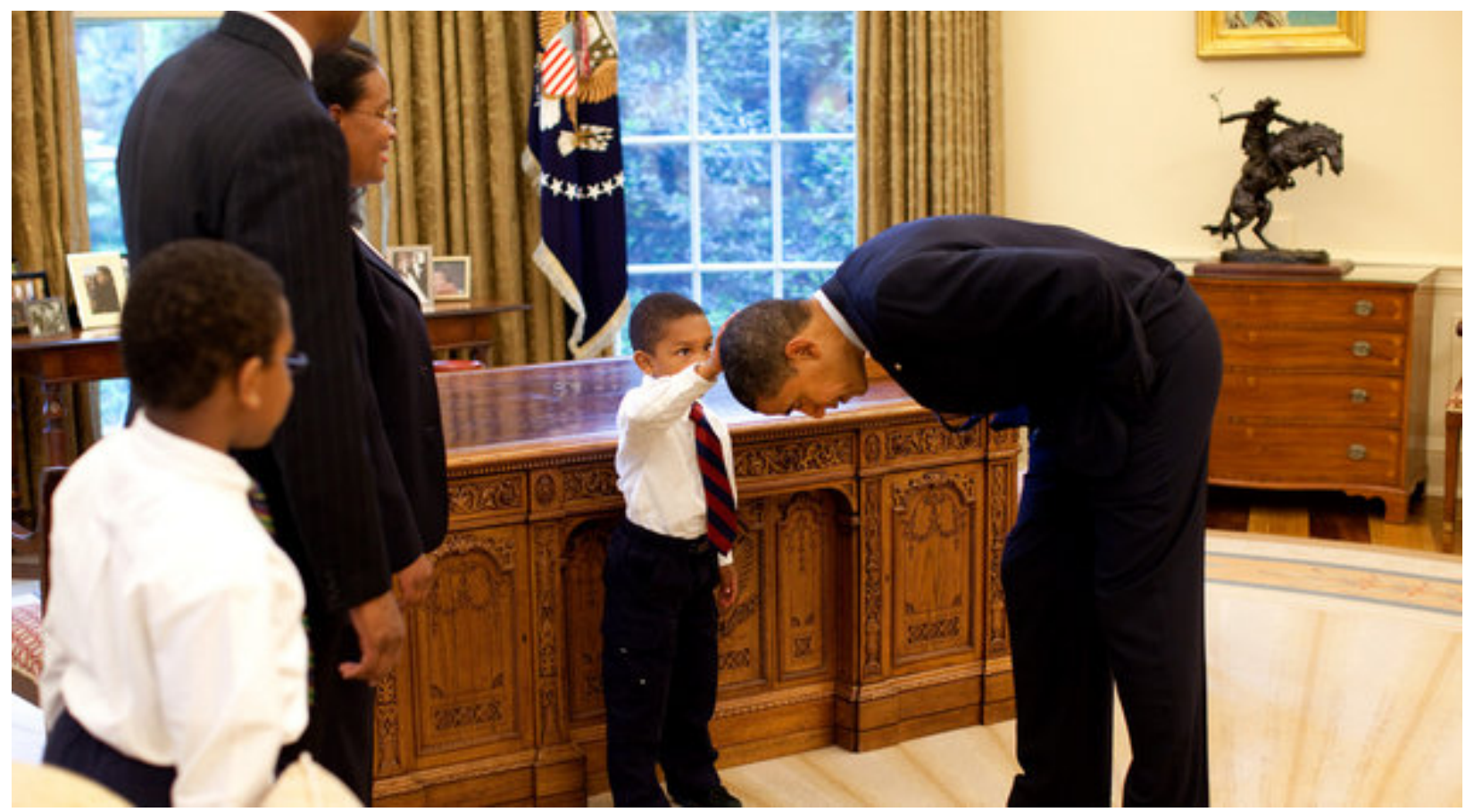

Pete Souza/The White House

http://www.nytimes.com/2012/05/24/us/politics/indelible-image-of-a-boys-pat-on-obamas-headhangs-in-white-house.html?smid=fb-share \&fb_source=message 


\section{On Multiculturalism and Diversity}

Well, I say ... tonight, there's not a liberal America and a conservative America; there is the United States of America . . . there is not a black America and white America and Latino America and Asian America; there's the United States of America ... We are one people, all of us pledging allegiance to the stars and stripes, all of us defending the United States of America.

Obama-Keynote at 2004 National Democratic convention

We worship an awesome God in the blue states and we don't like federal agents poking around in our libraries in the red states. We are one people, all of us pledging allegiance to the 'Stars and Stripes,' all of us defending the United States of America.

$$
\text { Obama-October 19, } 2006 \text { on Larry King }
$$

It's the answer spoken by young and old, rich and poor, Democrat and Republican, black. White, Latino, Asian, Native American, gay, straight, disabled and not disabled - Americans who sent a message to the world that we have never been a collection of Red States and Blue States; we are, and always will be, the United States of America

Obama-November 4, 2008: Historic election night victory

Acknowledging multiculturalism and the diversity that exists among us, Obama's ideology begs for the coming together of US citizens under the guise of Americanism, the glue that binds us. Embracing cultural diversity goes beyond morality; it is sensible and "as a nation, we are beginning to learn that we cannot succeed by exclusion, escape, and fraudulent notions of ourselves and each other. Negative externalities are beginning to catch up with us revealing devastating economic interdependency that makes sharing burdens and identifying common interests critical to the survival of our collective way of life" (Trout 6). Multiculturalism and inclusivity is practical for the classroom as well. Obama's call for the acceptance of diversity applies to the classroom. The classroom is the space where students should be granted an opportunity to not only address issues important to their own experiences but those of others even when the majority of them may be from a specific racial group or socio-economic background. It should be a safe space to examine what groups hold in common while simultaneously appreciating the differences that exist. This may be achieved by teaching single academic courses that address the value of multiculturalism but, more importantly, we can prepare our students for the multicultural world by ensuring that multicultural teaching is infused across the curriculum (Gay 2004). Resistant students need to be reminded of the multicultural make up of this nation and the world beyond it. Furthermore, the above quotes which outline the cultural make up of the US can be applied to the classroom setting by helping students to realize that we don't have white students or black students but learners-learners who bring different cultural representations, experiences, and varied identities to the table. They can only truly function as global citizens when they are exposed to the reality of not only the value of our connectedness but acceptance of differences as well, notably race. 
Springer, J.T.

\section{On Race.}

I never bought into the notion that by electing me, somehow we were entering into a post- period.

...race is an issue that I believe this nation cannot afford to ignore right now. We would be making the same mistake that Reverend Wright made in his offending sermons about America-to simplify comments that have been made and the issues that have surfaced over the last few weeks reflect the complexities of race in this country that we've never really worked through - a part of our union that we have yet to perfect. And if we walk away now, if we simply retreat into our respective comers, we will never be able to come together and solve challenges like health care, or education, or the need to find good jobs for every American.

Obama-Barack Obama's Speech on Race

For Obama, race is not the problem of the disadvantaged, but one that must be noted, addressed, and assessed by all. As a nation we have not, as Obama states, successfully worked through racial realities and, therefore, cannot turn a "color blind" eye to conversations of race especially in the name of having a black president. If Obama's "election signaled a post-racial time, we would expect to see blacks increase their foothold in the middle-class, increase their asset ownership and make greater gains in net financial worth relative to whites" (Troutt 2009). This has not happened. It is important to inform students who embrace post race rhetoric that structural racism and racial hierarchies are still in place. What post race ideologies and color blindness do collectively is stifle growth as well as induces a silence that ultimately disempowers people of color, blacks in particular. To establish a classroom where discussions of race are not included is to render invisible students who are non-white. In order to combat revisiting this invisibility it is important to continue discussions of race through the use of: historical texts which frame the history of race in this country and how it continues to affect ongoing racial disparities, even when some racial progress is noted; entertain the everyday realities of racial profiling and other such inequities in the classroom to reference every day realities of blacks and others of color who experience racial profiling and other inequities; create assignments where students are encouraged to engage with a different culture or group other than their own so that they have an opportunity to evaluate things through the eyes of others; and to reintroduce critical thinking as a tool. By this I mean that students who rely on the sound bites of a post race nation can be given assignments that ask them to question who is advocating post race narratives and why. Instead of accepting that rhetoric as gospel, find out what the alternative to post race thinking might be and investigate how this rhetoric impacts individuals from different groups rather than taking anything at face value. Race is still a viable facet of a multicultural education.

\section{On Gender and Sexuality}

I believe that discrimination because of somebody's sexual orientation or gender identity runs counter to who we are as a people. It's a violation of the basic tenets on which this nation was founded. I believe that gay couples deserve the same legal rights as every other couple in this country. . . we are going to keep on

Journal of the Scholarship of Teaching and Learning, Vol. 14, No. 3, August 2014. 
fighting until the law no longer treats committed partners who have been together for decades like they are strangers ... That's why I have long believed that the so called Defense of Marriage Act needs to be repealed . . it was wrong . . it was unfair.

\section{Obama 2012: Speech on Gay Marriage}

We know that our challenges are eminently solvable. The question is whether together, we can muster the will - in our own lives, in our common institutions, in our politics - to bring about the changes we need. And I'm convinced your generation possesses that will. And I believe that the women of this generation - that all of you will help lead the way.

\section{Obama:2012Commencement Address@Barnard College}

Today, women are not just half this country; you're half its workforce. More and more women are out-earning their husbands. You're more than half of our college graduates, and master's graduates, and PhDs. After decades of slow, steady, extraordinary progress, you are now poised to make this the century where women shape not only their own destiny but also the destiny of this nation and of this world.

\section{Obama: 2012 Commencement Address@Barnard College}

Obama's advocacy for female empowerment and gay rights is progressive and encouraging. It demonstrates his recognition of gender disparities and the unfair treatment of gay men and women. In ways that there is conversation about a post race nation, there is also a post that has been attached to feminism. Indeed much progress has been made in terms of women breaking glass ceilings but there are still many more to be shattered. Claims to post feminism, like post race rhetoric, suppresses healthy dialogue on how we might continue to forge ahead to secure equal rights for women. It is indeed a challenge to get younger generations of women to see the gender inequities thus including texts and assignments that address representations of women responsibly and exposing students to the continued struggles women endure is important. Furthermore, Obama's endorsement of Gay marriage is monumental and should be appropriated more in classrooms. My students who are typically undone when they have to examine issues of race would readily agree to do so rather than discuss issues related to sexual orientation. As instructors, we have not done enough to secure safe spaces for students whose sexual orientation deviates from the norm. Conversations about GLBT identities can add to and enrich the multicultural classroom as well as empower students who identify as such. Very few universities offer specializations in Gay and Lesbian Studies. It is usually tacked on to gender and cultural studies. It is imperative that we engage literature, film, and other useful texts that help us to engage students in conversations about sexual orientation. To omit discussions of sexual orientation is to also dismiss the subject location and experiences of gay and lesbian persons, denying them rights to rightful citizenship. Obama's 2013 Inauguration speech rightly captures his sensitivity to and understanding of the ways in which the above identities intersect as well as the road travelled by those disadvantaged by pre and post race/gender/sexuality identities: "We, the people, declare today that the most evident of truths - that all of us are created equal - is the star that guides us still; just as it guided our forebears through Seneca Falls, and Selma, and Stonewall; just as it guided all those men and women, sung and unsung, who left footprints along 
Springer, J.T.

this great Mall, to hear a preacher say that we cannot walk alone; to hear a King proclaim that our individual freedom is inextricably bound to the freedom of every soul on Earth.." (Washington Post, 2013).

\section{Conclusion}

Colorblind advocacy endangers and hinders possible progress in multicultural education. "Race continues to play a most potent role in American culture although we have yet to move beyond the quintessential black/white dichotomy in a manner that accurately and clearly begins to delineate the many shades of race" (James, 2009). Hence, claims to a post race nation due to the presence of a black president are unsustainable. The "change" that Obama mentioned that had "come to America" in his opening speech did not mean a change where race is transcended. If anything, it appears that the nation is more race conscious in the era of Obama. The hope for racial change is understandable and perhaps reasonable; however, it is more industrious to accept that, as Cornell West reminds us, "Race Matters." Thinking more astutely on how we can utilize the moment not to end discussions about race but to probe how we might complicate our understanding of it at this juncture and its role in multicultural and inclusive pedagogy proves most useful. Obama's bi-racial identity and culturally diverse lived experiences can function as useful examples of what diversity looks like and his politics demonstrative of how to capitalize on the diverse tools and ways of being within and outside of our respective communities. His identity, though contested, serves as a narrative we could all mimic if we were to embrace our multifaceted identities. Instructors and students alike can glean the relevance and potential of inclusive learning by following the example set in Obama's encouragement of a multicultural existence-one that does not deny race as a viable and necessary component. In the end such learning environments produce well-rounded students and help them become global citizens. ${ }^{3}$

\section{References}

Alexander, Michelle. (2010, 2012). The New Jim Crow. The New Press, New York: The New Press.

Ashburn-Nardo, Leslie and Robert Livingston "Implicit Bias: A Better Metric For Racial Progress.” (2011). The Obamas and a (Post) Racial America?” Eds. Gregory Parks and Matthew Hughes. New York, NY: Oxford University Press.

Chang, C. S., \& Treacy, M.J. (1996). "Resistance in Multicultural Courses: Student, Faculty, And Classroom Dynamics." American Behavioral Scientist, 40(2), pp. 212-221. doi: 10.1177/0002764296040002012

Cisneros, Sandra. (1991). The House on Mango Street. New York, NY: Vintage.

Jared. (2008). “Barack Obama, 'Connected Distance': Race and Twenty-First Century NeoColonialism.” The Black Scholar, 38(4), pp. 35-37.

3 Appropriated from Cornell West's Race Matters.

Journal of the Scholarship of Teaching and Learning, Vol. 14, No. 3, August 2014. 
Springer, J.T.

Banks, J.A. (1994). "The Importance of Multicultural Education. Educational Leadership. May, 4-8.

Banks, J. A. (2008). An Introduction to Multicultural Education. Seattle, WA: Pearson/Allyn.

Banks, J. A. (2005). Improving Multicultural Education: Lessons from the Intergroup Education Movement. New York, NY: Teachers College Publishing.

Cornell, S. E. and Douglas Hartmann. (1998). Ethnicity and Race: Making Identities In a Changing World. Thousand oaks, CA: Pine Forge Press.

Danticat, Edwidge. (1998). Breath, Eyes, Memory. New York: Vintage.

Gay, G. (2004). “The Importance of Multicultural Education.” Educational Leadership. Dec: 30-35.

Gay, G. (2204) "Beyond Brown: Promoting Equality Through Multicultural Education. Journal of Curriculum and Supervision, 19(3), pp. 193-216.

Hill, Rickey. (2009). "The Race Problematic, the Narrative of Martin Luther King Jr., and the of Barack Obama.”Souls, 11(1), pp. 60-78. doi: 10.1080/10999940902734911

Hooks, bell. (1994). Teaching to Transgress: Education as the Practice of Freedom. New York, NY: Routledge.

Hurtado, S., Milem, J., Clayton-Pedersen, A., \& Allen, W. (1999). Enacting Diverse Learning Environments: Improving the Climate for Racial/Ethnic Diversity in Higher Education.

Washington, D.C.: The George Washington University Press.

Ladson-Billings, Gloria. (1996). "Your Blues Ain't Like Mine': Keeping Issues of Race and Racism on the Multicultural Agenda. Theory Into Practice, 35(4), pp. 248-255.

Leonard, Zeus. (2011). "After the Glow: Race Ambivalence and Other Educational Prognoses." Educational Philosophy and Theory, 43(6), pp. 675-698. doi: 10.1111/j.1469-5812.2010.00645.x

James, Stanley. (2009). “Barack Obama: Coalitions of a Purple Mandate. Souls, 11(1), pp. 51-59.

Kitano, M. K. (1997). What a Course Will Look Like After Multicultural Change. In A. I. Morey \& M. K. Kitano (Eds.). (1997). Multicultural Course Transformation in Higher Education: A Broader Truth. Boston, MA: Allyn Bacon.

Khaja, Khadija, Jennifer Thorington Springer, Gina Sanchez Gibau, Silvia Bigatti, and Kathy Grove. 2010. "Multicultural Teaching: Barriers and Recommendations." Journal of Teaching Excellence, 21(4), pp. 49-74.

Lee, Taeku. (2011). "Somewhere Over the Rainbow? Post-Racial \& Pan-Racial Politics in the 
Springer, J.T.

Age of Obama. Daedalus, the Journal of the American Academy of Arts \& Sciences, 140(2): 136-150.

MacIntosh, Peggy. (1988). "White Privilege: Unpacking the Invisible Knapsack." Race, Class and Gender in the United States, An Integrated Study. Ed. Paula S. Rothenberg. New York, NY: Worth Publishers. 188-192.

Marable, Manning. (2009). "Racializing Obama: The Enigma of Post-Black Politics and Leadership.” Souls, 11(1), pp. 1-15. doi: 10.1080/10999940902733202

Marshall, Patricia. (2009). "Multicultural Education in a Post-Race Age: Our Movement at Risk?” Multicultural Perspectives, 11(4), pp. 188-193. doi: 10.1080/15210960903445863

Nagda, B. A., Spearmon, M. L., Holley, L. C., Harding, S., Balassone, M. L., MoiseSwanson, D. and de Mello, S. (1999). 'Intergroup Dialogues: An Innovative Approach to Teaching About Diversity and Justice in Social Work Programs. Journal of Social Work Education, 35(3), pp. 433-49.

Ngozi Adichie, Chimamanda. (2003). Purple Hibiscus. New York, NY: Algonquin.

Ono, Kent. A. "Postracism: A Theory of the "Post"-as Political Strategy. Journal of Communication Inquiry, 34(2), pp. 227-233.

Parameswaran, Radhika. (2012). "Facing Barack Hussein Obama: Race, Globalization, and Transnational America." Journal of Communication Inquiry, 33(3), pp. 195-205. doi: $10.1177 / 0196859909333896$

Rossing, Jonathan. (2012). "Deconstructing Postracialism: Humor as Critical, Cultural Project." Journal of Communication Inquiry, 36(1), pp. 44-61. doi: 10.1177/0196859911430753

Sheets, R.H. (2005). Diversity Pedagogy: Examining the Role of Culture in the TeachingLearning Process. Boston, MA: Pearson Education.

Smith, Rogers M and Desmond S. King. (2009). "Barack Obama and the Future of American Racial Politics." Du Bois Review, 6(1), pp. 25-35.

Swarns, Rachel. L. (2012). American Tapestry: The Story of the Black, White, and Multicultural Ancestors of Michelle Obama. New York, NY: Harper Collins Publishing.

Thorington Springer, Jennifer. (2006). "Reflection of Diversity Practices: Surviving Student Resistance in the Classroom." Growing Through Our Past into the Future: Journeys of Educators on the Path to Cultural Competence. Ed. Marla Zimmerman. http://ctl.iupui.edu/diversity/essays.html

Troutt, David. (2009). "Barack Obama, 'Post-Raciality' and Mythic-Rhetorical Regime Change." Columbia Law School Conference Proceedings. 
Springer, J.T.

West, Cornell. (1994). Race Matters. New York: Vintage.

Wlodkowski, Raymond J. and Margery B. Gingsberg. (1995). Diversity and Motivation: Culturally Responsive Teaching. San Francisco, CA: Jossey Bass Publishing. 